\title{
RANCANG BANGUN APLIKASI UNTUK MEMPREDIKSI STATUS GIZI BALITA
}

\author{
Muhammad Nurtanzis Sutoyo \\ Universitas Sembilanbelas November Kolaka \\ Jl. Pemuda No. 339 Kolaka Sulawesi Tenggara \\ mns.usn21@gmail.com
}

\begin{abstract}
Nutrition problems can occur in every phase of life, starting from the womb until the elderly. Application of K-Nearest Neighborhood (k-NN) method can help predict the nutritional status of children under five. The $k-N N$ algorithm is a method to classify objects based on learning data closest to the object. Based on the results of research, it can be concluded that the $k$-NN algorithm can predict the nutritional status of children.
\end{abstract}

Keywords: Nutrition, $k N N$

\begin{abstract}
Abstrak
Masalah gizi dapat terjadi disetiap fase kehidupan, dimulai sejak dalam kandungan sampai dengan usia lanjut. Penerapan Metode K-Nearest Neighborhood (k-NN) dapat membantu memprediksi status gizi balita. Algoritma $k$-NN merupakan sebuah metode untuk melakukan klasifikasi terhadap objek berdasarkan data pembelajaran yang jaraknya paling dekat dengan objek tersebut. Berdasarkan hasil penelitian, maka dapat disimpulkan bahwa algoritma $k$-NN dapat memprediksi status gizi balita.
\end{abstract}

Kata kunci: Gizi, KNN

\section{PENDAHULUAN}

Memiliki gizi yang baik adalah syarat utama dalam mewujudkan sumber daya manusia yang berkualitas. Masalah gizi dapat terjadi disetiap fase kehidupan, dimulai sejak dalam kandungan sampai dengan usia lanjut. Fase bayi atau balita merupakan dimana fase masa pertumbuhan dan perkembangan yang sangat pesat. Apabila pada fase tersebut mengalami gangguan gizi maka akan bersifat permanen sampai fase selanjutnya, walaupun kebutuhan gizi pada masa selanjutnya terpenuhi[1].

Indonesia sebagai salah satu negara dengan kompleksitas penduduk yang sangat beraneka ragam dihadapi oleh dinamika persoalan gizi buruk[2]. Walaupun proses pembangunan di Indonesia telah mampu mengatasi persoalan gizi, tetapi jika dilihat dari data statistik, masih banyak persoalan yang perlu diselesaikan terutama yang menyangkut persoalan gizi[3].

Faktor-faktor yang mempengaruhi terjadinya gizi buruk, yaitu: status sosial ekonomi, ketidaktahuan ibu tentang pemberian gizi yang baik untuk anak, dan Berat Badan Lahir Rendah (BBLR). Sumber lain menyebutkan bahwa asupan 
makanan keluarga, faktor infeksi, dan pendidikan ibu menjadi penyebab kasus gizi buruk[4].

Penerapan Metode K-Nearest Neighborhood ( $k$-NN) dapat membantu memprediksi status gizi anak yang diperoleh dari kondisi anak tersebut. $K$-NN adalah suatu metode yang menggunakan algoritma supervised dimana hasil dari query instance yang baru diklasifikasikan berdasarkan mayoritas dari label class pada $k$-NN[5]. Jadi tujuan dari algoritma $k$-NN adalah mengklasifikasikan objek baru berdasarkan atribut dan training data.

Algoritma $k$-NN bekerja berdasarkan jarak terpendek dari query instance ke training data untuk menentukan $k$-NN-nya. Salah satu cara untuk menghitung jarak dekat atau jauhnya tetangga menggunakan metode euclidian distance.

Dalam Algoritma $k$-NN terdapat salah satu parameter yaitu $k$. Pemilihan nilai $k$ menjadi hal yang penting, karena akan mempengaruhi kinerja algoritma $k$ $\mathrm{NN}[6]$. Nilai $k$ yang terlalu kecil, akan mempengaruhi hasil klasifikasi. Di sisi lain, jika nilai $k$ terlalu tinggi akan mengurangi efek noise pada klasifikasi, tetapi membuat batasan antara setiap klasifikasi menjadi lebih kabur. Nilai $k$ yang bagus dapat dipilih dengan optimasi parameter, misalnya dengan menggunakan crossvalidation. Sampai saat ini belum diketahui berapa nilai $k$-Optimal dalam algoritma $k$-NN dalam suatu studi kasus yang diteliti.

Begitu pula penelitian yang menggunakan algoritma $k$-NN banyak sekali ditemui dengan berbagai macam persoalan. Seperti[7] menggunakan algoritma $k$ NN untuk memprediksi kelulusan tepat waktu mahasiswa. Hasil dari penelitian tersebut bahwa dengan menggunakan algoritma $k$-NN dapat memprediksi kelulusan tepat waktu mahasiswa berdasarkan IP sampai dengan semester 4 adalah sebesar $80 \%$.

Begitu pula[8] menggunakan algoritma $k$-NN untuk memprediksi predikat prestasi mahasiswa. Hasil dari penelitian tersebut bahwa dengan menggunakan algoritma $k$-NN dapat memprediksi predikat prestasi mahasiswa dengan tingkat akurasi sebesar $82 \%$.

Begitu pula[9] menggunakan algoritma $k$-NN untuk memprediksi siswa berprestasi. Hasil dari penelitian tersebut bahwa dengan menggunakan algoritma $k$-NN dapat memprediksi siswa berprestasi dengan tingkat akurasi sebesar $76,67 \%$.

Sedangkan dalam penelitian ini, algoritma $k$-NN digunakan untuk memprediksi status gizi anak. Dimana dalam memprediksi status gizi anak dengan algoritma $k$-NN menggunakan 3 variabel, yaitu: umur (tahun), berat badan (kg), dan tinggi badan $(\mathrm{cm})$.

\section{METODOLOGI PENELITIAN}

\subsection{Tahapan Penelitian}

Tahapan penelitian menggunakan model sekuensial linear biasa disebut siklus hidup klasik (classic life cycle) atau model air terjun (Waterfall). Dimana model sekuensial linear menyarankan pendekatan sistematis dan 5 sekuensial untuk pengembangan perangkat lunak yang dimulai pada analisis, desain, pengkodean, pengujian, dan pemeliharaan. Gambar 1 menggambarkan model sekuensial linear[10]. 


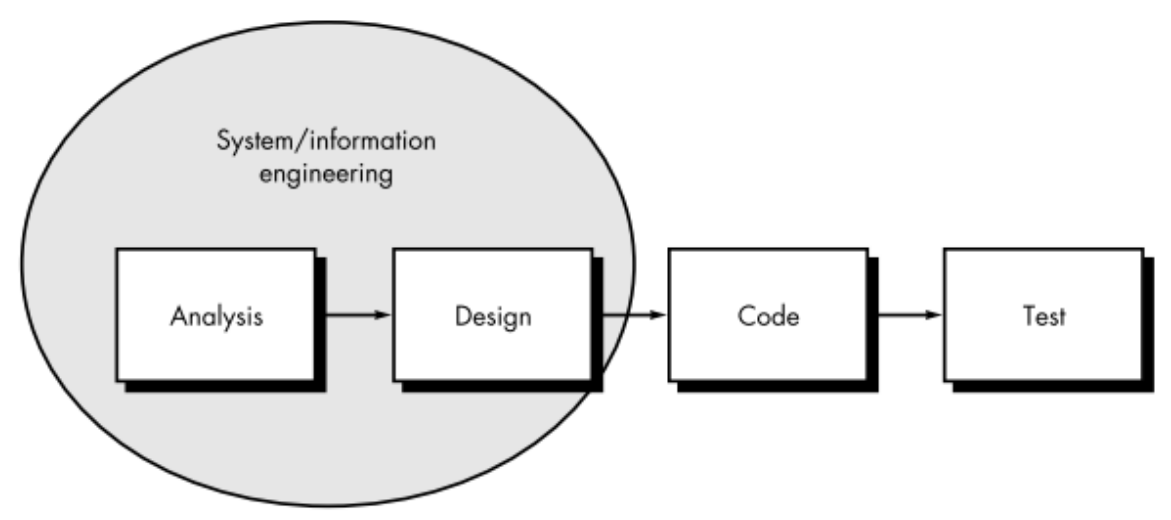

Gambar 1. Model Sekuensial Linear (Waterfall)

Berikut ini penjelasan yang bisa diberikan untuk masing-masing tahap:

a. Analysis

Proses pengumpulan kebutuhan difokuskan khususnya untuk perangkat lunak, perekayasa perangkat lunak (Analis) harus memahami domain permasalahan (problem domain), tingkah laku, unjuk kerja dan antarmuka (interface) yang diperlukan.

b. Design

Desain perangkat lunak sebenarnya adalah proses multi langkah yang berfokus pada empat atribut sebuah program yang berbeda (struktur data, arsitektur perangkat lunak, representasi interface, dan detail (algoritma) prosedural. Proses desain menerjemahkan syarat/kebutuhan ke dalam sebuah representasi perangkat lunak yang dapat diperkirakan demi kualitas sebelum dimulai pemunculan kode (coding).

c. Code

Desain harus diterjemahkan ke dalam bentuk mesin yang bisa dibaca. Langkah pembuatan kode meliputi pekerjaan dalam langkah ini, dan dapat dilakukan secara mekanis.

d. Test

Sekali kode dibuat, pengujian program dimulai. Proses pengujian berfokus pada logika internal perangkat lunak, memastikan bahwa semua pernyataan sesudah diuji, dan pada eksternal fungsional, yaitu mengarahkan pengujian untuk menemukan kesalahan-kesalahan dan memastikan bahwa input yang dibatasi akan memberikan hasil aktual yang sesuai dengan hasil yang dibutuhkan.

e. Pemeliharaan

Perangkat lunak akan mengalami perubahan setelah disampaikan kepada pelanggan (perkecualian yang mungkin adalah perangkat lunak yang dilekatkan). 


\subsection{Teknik Pengumpulan Data}

Pengumpulan data dilakukan dengan dua cara, yaitu studi pustaka dan wawancara.

a. Studi pustaka

Kegiatan studi pustaka dilakukan dengan mempelajari literatur-literatur yang mendukung penelitian. Literatur yang dipelajari berkaitan dengan algoritma $k$-NN. Dimana literatur diperoleh dari berbagai sumber antara lain dari jurnal ilmiah dan buku.

b. Wawancara

Wawancara dilakukan dengan melakukan tanya jawab secara langsung kepada pihak yang memiliki kapasitas dan informasi yang dibutuhkan dalam pelaksanaan penelitian.

\subsection{Data Mining}

Data mining melibatkan integrasi teknik dari berbagai disiplin ilmu seperti database dan data warehouse teknologi, statistik, pengenalan pola, jaringan saraf, visualisasi data, serta pemrosesan sinyal. Oleh karena itu, data mining dianggap salah satu bidang ilmu yang paling penting dalam database dan sistem informasi sebagai salah satu bidang yang paling menjanjikan dalam perkembangan interdisipliner dalam teknologi informasi. Tujuan data mining adalah untuk mendapatkan pengetahuan (knowledge) yang sebelumnya tersimpan di dalam sejumlah kumpulan teks[11].

Secara umum, data mining dapat melakukan dua hal yaitu memberikan kesempatan untuk menemukan informasi menarik yang tidak terduga dan juga bisa menangani data berskala besar. Dalam menemukan informasi yang menarik ini, ciri khas data mining adalah kemampuan pencarian secara hampir otomatis, karena dalam banyak teknik data mining ada beberapa parameter yang masih harus ditentukan secara manual atau semi manual. Data mining juga dapat memanfaatkan pengalaman atau bahkan kesalahan di masa lalu untuk meningkatkan kualitas dari model maupun hasil analisanya, salah satunya dengan kemampuan pembelajaran yang dimiliki beberapa teknik data mining seperti klasifikasi[12].

\subsection{KNN}

Algoritma $k$-NN merupakan sebuah metode untuk melakukan klasifikasi terhadap objek berdasarkan data pembelajaran yang jaraknya paling dekat dengan objek tersebut[6]. Ketepatan algoritma $k$-NN sangat dipengaruhi ada atau tidaknya fitur-fitur yang relevan.

Nilai $k$ yang terbaik pada algoritma $k$-NN tergantung pada data. Secara umum, nilai $k$ yang tinggi akan mengurangi efek noise pada klasifikasi. Nilai $k$ yang bagus dapat dipilih dengan optimasi parameter, misalnya dengan menggunakan cross-validation. Jumlah kelas yang paling banyak dengan jarak terdekat tersebut akan menjadi kelas dimana data evaluasi tersebut berada.

Algoritma $k$-NN adalah sebagai berikut.

a. Tentukan parameter $k=$ jumlah tetangga terdekat 
b. Hitung jarak antara data yang akan dievaluasi dengan semua data pelatihan. Secara umum untuk mendefinisikan jarak antara dua objek $x$ dan $y$, digunakan rumus jarak Euclidean pada persamaan berikut.

$$
d(x, y)=\sqrt{\sum_{k=1}^{n}\left(x_{k}-y_{k}\right)^{2}}
$$

c. Urutkan jarak yang terbentuk (urut naik) dan tentukan jarak terdekat sampai urutan ke- $k$

d. Pasangkan kelas (c) yang bersesuaian

e. Cari jumlah kelas terbanyak dari tetangga terdekat tersebut, dan tetapkan kelas tersebut sebagai kelas data yang dievaluasi.

\subsection{Gizi Buruk}

Gizi buruk merupakan istilah teknis yang biasanya digunakan oleh kalangan gizi, kesehatan dan kedokteran. Secara umum status gizi dibagi menjadi tiga kelompok, yaitu[13]:

a. Kecukupan Gizi (Gizi Seimbang)

Dalam hal ini asupan gizi, seimbang dengan kebutuhan gizi seseorang yang bersangkutan.

b. Gizi Kurang

Gizi kurang merupakan keadaan tidak sehat yang timbul karena tidak cukup makan, dengan demikian konsumsi energi dan protein kurang selama jangka waktu tertentu.

c. Gizi Lebih

Keadaan patologis (tidak sehat) yang disebabkan kebanyakan makan.

Lebih lanjut[13] menjelaskan bahwa penyakit gangguan gizi banyak ditemui pada masyarakat golongan rentan, yaitu golongan yang mudah sekali menderita akibat kekurangan gizi dan juga kekurangan makanan (dificiency) misalnya kwashiorkor, busung lapar, marasmus, beri-beri dan lain-lain. Kegemukan (obesity), kelebihan berat badan (over weight) merupakan tanda gizi salah yang berdasarkan kelebihan dalam makanan.

Untuk mengetahui status gizi, diperlukan Penilaian Status Gizi (PSG). PSG adalah interpretasi dari data yang didapatkan dengan menggunakan berbagai metode untuk mengidentifikasi populasi atas individu yang berisiko atau dengan status gizi buruk[14].

Penentuan status gizi dapat dilakukan dengan berbagai cara, yaitu: secara biokimia, dietetika, klinik, dan antropometri. Sedangkan cara yang paling umum dan mudah digunakan untuk mengukur status gizi di lapangan adalah dengan cara antropometri. Dimana data yang digunakan adalah berat badan per umur (BB/U), Tinggi Badan per Umur (TB/U), Berat Badan per Tinggi Badan (BB/TB).

\section{HASIL DAN PEMBAHASAN}

\subsection{Deskripsi Sistem}

Penelitian ini berfokus pada prediksi status gizi balita. Dimana klasifikasi status gizi balitas dibagi menjadi 2 (dua), yaitu gizi buruk dan gizi baik. Metode 
yang digunakan untuk memprediksi status gizi balita adalah $k$-NN. Sedangkan variabel yang digunakan sebanyak 3 (tiga) variabel, yaitu: berat badan (BB), Tinggi Badan (TB), dan umur.

\subsection{Penerapan $k$-NN Untuk Prediksi}

Data diperoleh dari hasil penelitian[15] yang berjumlah 56 orang balita. Dimana data training disajikan pada Tabel 1. Tabel 1. Data Training

\begin{tabular}{ccccc}
\hline No & $\begin{array}{c}\text { Umur } \\
(\text { Tahun })\end{array}$ & BB $(\mathrm{Kg})$ & $\begin{array}{c}\text { TB } \\
(\mathrm{Cm})\end{array}$ & Status Gizi \\
\hline 1 & 4.00 & 11.7 & 86 & Buruk \\
2 & 4.10 & 12.07 & 90 & Buruk \\
3 & 1.40 & 7.60 & 58 & Buruk \\
4 & 2.00 & 9.00 & 75 & Buruk \\
5 & 4.00 & 14.00 & 103 & Buruk \\
6 & 4.00 & 11.80 & 87 & Buruk \\
7 & 4.50 & 14.00 & 105 & Buruk \\
8 & 3.50 & 10.70 & 84 & Buruk \\
9 & 3.00 & 12.10 & 89 & Buruk \\
10 & 2.00 & 10.50 & 96 & Buruk \\
$\ldots$ & $\ldots$ & $\ldots$ & $\ldots$ & $\ldots$ \\
$\ldots$ & $\ldots$ & $\ldots$ & $\ldots$ & $\ldots$ \\
50 & 2.02 & 12.50 & 74 & Baik \\
51 & 1.05 & 10.70 & 74 & Baik \\
52 & 1.00 & 9.50 & 69 & Baik \\
53 & 3.04 & 18.80 & 100 & Baik \\
54 & 2.00 & 13.80 & 89 & Baik \\
55 & 2.06 & 15.30 & 86 & Baik \\
56 & 1.02 & 10.90 & 74 & Baik \\
\hline
\end{tabular}

Kemudian diberikan sebuah kasus seorang anak yang ingin diketahui apakah gizi buruk atau gizi baik. Adapun kondisi anak tersebut dengan kondisi berat badan $12.30 \mathrm{Kg}$, tinggi badan $70 \mathrm{~cm}$, dan umur 2 tahun.

Langkah-langkah penyelesaian sebagai berikut.

a. Kita tentukan nilai $k$, misal $k=19$.

b. Selanjutnya terlebih dahulu jarak data yang akan dievaluasi, yaitu $y=(2,12.3$, 70) terhadap setiap data training dengan menggunakan rumus jarak Euclidean. c.

Tabel 2. Hitung Jarak

\begin{tabular}{ccccc}
\hline $\begin{array}{c}\text { Umur } \\
\text { (Tahun) }\end{array}$ & BB $(\mathrm{Kg})$ & TB $(\mathrm{Cm})$ & Jarak & Status Gizi \\
\hline 4.00 & 11.7 & 86 & $\mathrm{~d}=\sqrt{(4.00-2.00)^{2}+(11.7-12.3)^{2}+(86-70)^{2}}=18.60$ & Buruk \\
4.10 & 12.07 & 90 & $d=\sqrt{(4.10-2.00)^{2}+(12.07-12.3)^{2}+(90-70)^{2}}=22.33$ & Buruk \\
1.40 & 7.60 & 58 & $d=\sqrt{(1.04-2.00)^{2}+(7.60-12.3)^{2}+(58-70)^{2}}=17.30$ & Buruk
\end{tabular}


Kumpulan jurnaL Ilmu Komputer (KLIK) Volume 05, No.02 September 2018

ISSN: 2406-7857

\begin{tabular}{|c|c|c|c|c|}
\hline $\begin{array}{l}\text { Umur } \\
\text { (Tahun) }\end{array}$ & $\mathrm{BB}(\mathrm{Kg})$ & $\mathrm{TB}(\mathrm{Cm})$ & Jarak & Status Gizi \\
\hline 2.00 & 9.00 & 75 & $d=\sqrt{(2.00-2.00)^{2}+(9.00-12.3)^{2}+(75-70)^{2}}=8.30$ & Buruk \\
\hline 4.00 & 14.00 & 103 & $d=\sqrt{(4,00-2,00)^{2}+(14,00-12.3)^{2}+(103-70)^{2}}=36.70$ & Buruk \\
\hline 4.00 & 11.80 & 87 & $d=\sqrt{(4.00-2.00)^{2}+(11.80-12.3)^{2}+(87-70)^{2}}=19.50$ & Buruk \\
\hline 4.50 & 14.00 & 105 & $d=\sqrt{(4.50-2.00)^{2}+(14.0-12.3)^{2}+(105-70)^{2}}=39.20$ & Buruk \\
\hline 3.50 & 10.70 & 84 & $d=\sqrt{(3.50-2.00)^{2}+(10.70-12.3)^{2}+(84-70)^{2}}=17.10$ & Buruk \\
\hline 3.00 & 12.10 & 89 & $d=\sqrt{(3.00-2.00)^{2}+(12.10-12.3)^{2}+(89-70)^{2}}=20.20$ & Buruk \\
\hline 2.00 & 10.50 & 96 & $d=\sqrt{(2.00-2.00)^{2}+(10.50-12.3)^{2}+(96-70)^{2}}=27.80$ & Buruk \\
\hline$\cdots$ & $\cdots$ & $\cdots$ & $\cdots$ & $\cdots$ \\
\hline ... & $\cdots$ & $\ldots$ & $\ldots$ & $\ldots$ \\
\hline 2.02 & 12.50 & 74 & $d=\sqrt{(2.02-2.00)^{2}+(12.50-12.3)^{2}+(74-70)^{2}}=4.22$ & Baik \\
\hline 1.05 & 10.70 & 74 & $d=\sqrt{(1.05-2.00)^{2}+(10.70-12.3)^{2}+(74-70)^{2}}=6.55$ & Baik \\
\hline 1.00 & 9.50 & 69 & $d=\sqrt{(1.00-2.00)^{2}+(9.50-12.3)^{2}+(69-70)^{2}}=4.80$ & Baik \\
\hline 3.04 & 18.80 & 100 & $d=\sqrt{(3.04-2.00)^{2}+(18.80-12.3)^{2}+(100-70)^{2}}=37.54$ & Baik \\
\hline 2.00 & 13.80 & 89 & $d=\sqrt{(2.00-2.00)^{2}+(13.80-12.3)^{2}+(89-70)^{2}}=20.50$ & Baik \\
\hline 2.06 & 15.30 & 86 & $d=\sqrt{(2.06-2.00)^{2}+(15.30-12.3)^{2}+(86-70)^{2}}=19.06$ & Baik \\
\hline 1.02 & 10.90 & 74 & $d=\sqrt{(1.02-2.00)^{2}+(10.90-12.3)^{2}+(74-70)^{2}}=6.38$ & Baik \\
\hline
\end{tabular}

d. Urutkan jarak yang terbentuk (urut naik) dan tentukan jarak terdekat sampai urutan ke-19

Tabel 3. Hasil Pengurutan

\begin{tabular}{ccccccc}
\hline No & $\begin{array}{c}\text { Data } \\
\text { Ke- }\end{array}$ & $\begin{array}{c}\text { Umur } \\
\text { (Tahun) }\end{array}$ & BB (Kg) & $\begin{array}{c}\text { TB } \\
(\mathrm{Cm})\end{array}$ & Kategori & Jarak \\
\hline 1 & 40 & 2.09 & 11.40 & 70 & Baik & 0.990 \\
2 & 36 & 2.00 & 10.30 & 70 & Baik & 2.000 \\
3 & 44 & 2.00 & 12.20 & 73 & Baik & 3.100 \\
4 & 32 & 2.01 & 11.20 & 72 & Baik & 3.110 \\
5 & 47 & 1.05 & 11.00 & 69 & Baik & 3.250 \\
6 & 30 & 1.01 & 10.10 & 69 & Baik & 4.190 \\
7 & 50 & 2.02 & 12.50 & 74 & Baik & 4.220 \\
8 & 46 & 1.05 & 10.60 & 72 & Baik & 4.650 \\
9 & 52 & 1.00 & 9.50 & 69 & Baik & 4.800 \\
10 & 35 & 2.00 & 11.50 & 75 & Baik & 5.800 \\
11 & 56 & 1.02 & 10.90 & 74 & Baik & 6.380 \\
12 & 39 & 1.02 & 10.80 & 74 & Baik & 6.480 \\
13 & 51 & 1.05 & 10.70 & 74 & Baik & 6.550 \\
14 & 48 & 1.05 & 10.60 & 65 & Baik & 7.650 \\
15 & 31 & 2.09 & 11.40 & 77 & Baik & 7.990 \\
16 & 4 & 2.00 & 9.00 & 75 & Buruk & 8.300 \\
17 & 42 & 2.00 & 12.00 & 79 & Baik & 9.300 \\
18 & 41 & 2.02 & 12.30 & 80 & Baik & 10.020
\end{tabular}




\begin{tabular}{ccccccc}
\hline No & $\begin{array}{c}\text { Data } \\
\text { Ke- }\end{array}$ & $\begin{array}{c}\text { Umur } \\
\text { (Tahun) }\end{array}$ & BB $(\mathrm{Kg})$ & $\begin{array}{c}\text { TB } \\
(\mathrm{Cm})\end{array}$ & Kategori & Jarak \\
\hline 19 & 43 & 2.03 & 12.40 & 80 & Baik & 10.130 \\
$\ldots$ & $\ldots$ & $\ldots$ & $\ldots$ & $\ldots$ & $\ldots$ & $\ldots$ \\
$\ldots$ & $\ldots$ & $\ldots$ & $\ldots$ & $\ldots$ & $\ldots$ & $\ldots$ \\
54 & 53 & 3.04 & 18.80 & 100 & Baik & 37.540 \\
55 & 7 & 4.50 & 14.00 & 105 & Buruk & 39.200 \\
56 & 33 & 4.00 & 14.90 & 120 & Baik & 54.600 \\
\hline
\end{tabular}

e. Pada urutan 1 s/d 19, ada 18 kategori Gizi Baik dan 1 kategori Gizi Buruk. Sehingga untuk data evaluasi $y=(2,12.3,70)$ termasuk dalam kategori Gizi Baik.

\subsection{Implementasi $\boldsymbol{k}$-NN Untuk Prediksi}

Tahapan implementasi merupakan tahapan dimana sistem yang telah di rancang dan dibangun untuk selanjutnya dioperasikan sebagaimana mestinya sesuai dengan fungsi untuk digunakan oleh pihak yang membutuhkan agar mewujudkan sistem yang telah dirancang. Dimana unsur yang dipertimbangkan dalam pembangunan sistem komputerisasi yaitu masalah perangkat lunak (software), karena perangkat lunak yang digunakan haruslah sesuai dengan masalah yang akan diselesaikan.

Sedangkan bentuk tampilan halaman dialog aplikasi prediksi status gizi balita ini disajikan seperti Gambar 2 dan Gambar 3.

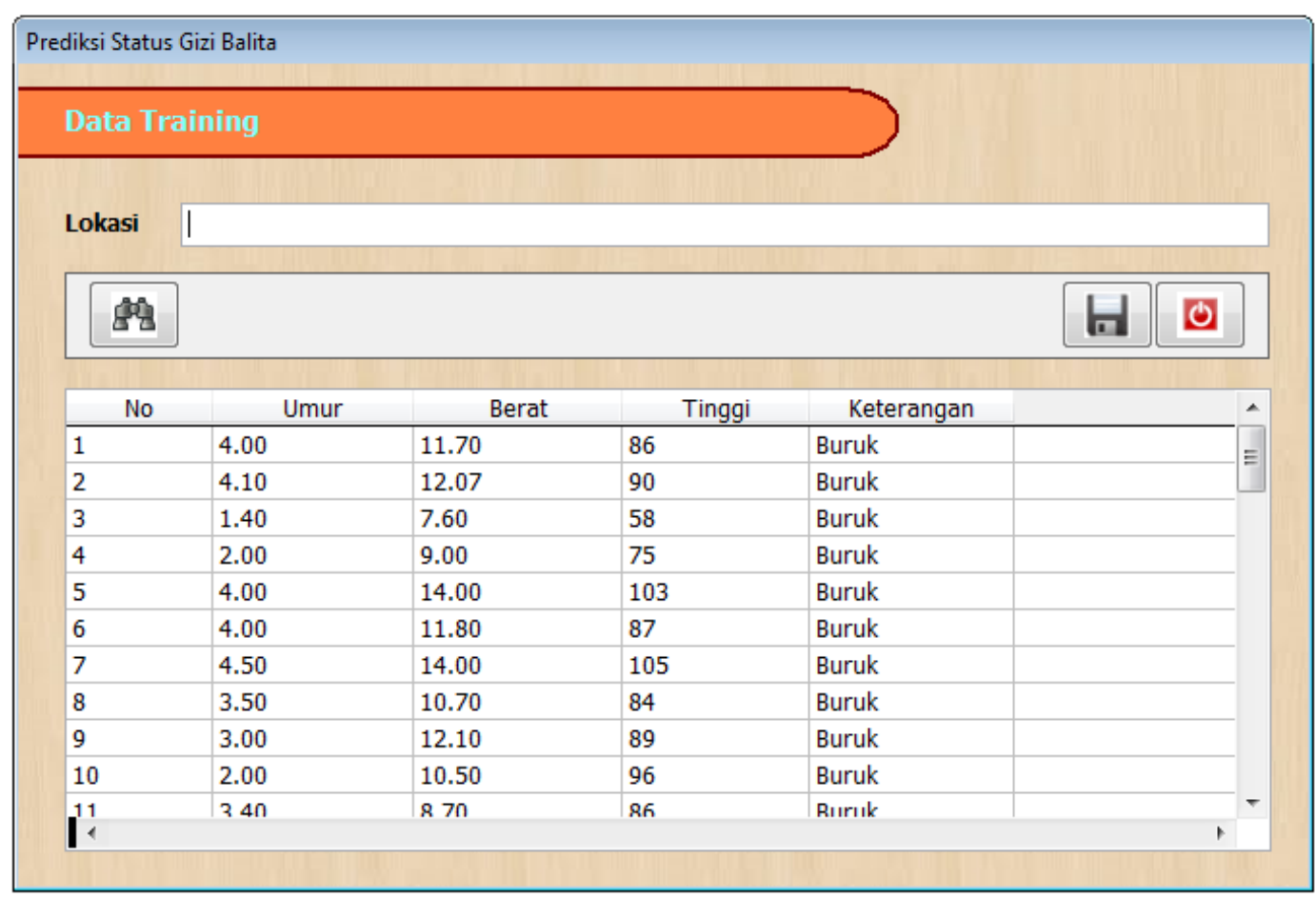

Gambar 2. Halaman Dialog Data Training 


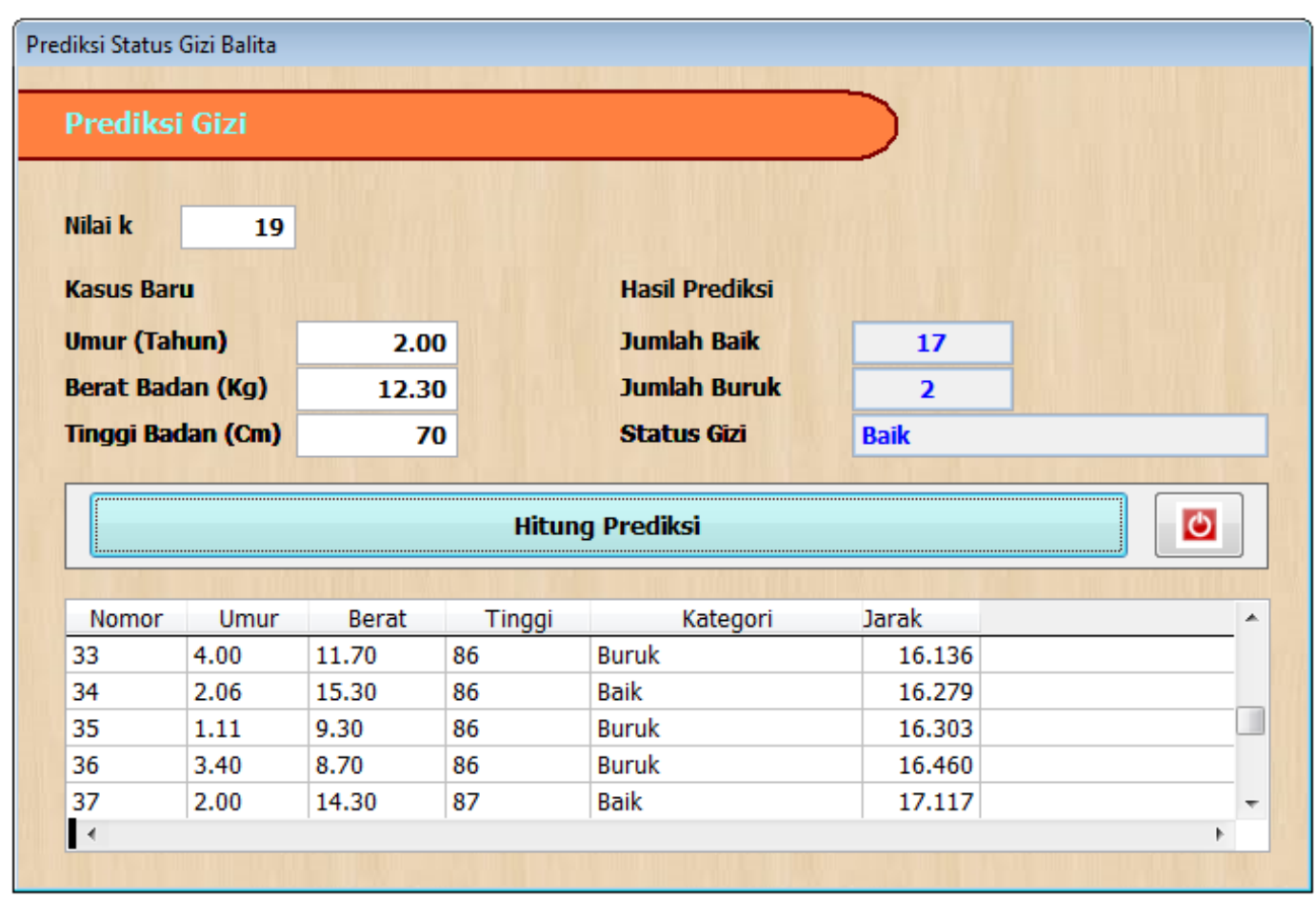

Gambar 3. Halaman Dialog Prediksi

Apabila diberikan nilai $k$ yang secara bervariasi, maka hasil data evaluasi $y=(2,12.3,70)$ prediksi status gizi balita seperti Tabel 3 .

Tabel 3. Hasil Prediksi Nilai $k$ bervariasi

\begin{tabular}{|c|c|c|c|}
\hline \multirow{2}{*}{ Nilai $k$} & \multicolumn{2}{|c|}{ Jumlah } & \multirow{2}{*}{ Kategori } \\
\hline & Baik & Buruk & \\
\hline 11 & 11 & 0 & Baik \\
\hline 13 & 13 & 0 & Baik \\
\hline 15 & 14 & 1 & Baik \\
\hline 17 & 15 & 2 & Baik \\
\hline 19 & 17 & 2 & Baik \\
\hline 21 & 19 & 2 & Baik \\
\hline
\end{tabular}

Berdasarkan Tabel 3 apabila nilai $k$ diberikan secara bervariasi dengan data evaluasi $y=(2,12.3,70)$ maka sistem yang dibagun memberikan prediksi bahwa data evaluasi termasuk dalam kategori Gizi Baik.

\section{SIMPULAN}

Berdasarkan hasil penelitian, maka dapat disimpulkan bahwa algoritma $k$ NN dapat memprediksi status gizi balita. Hal ini diketahui apabila nilai $k$ diberikan secara bervariasi dengan data evaluasi $y=(2,12.3,70)$ maka sistem yang dibagun memberikan prediksi bahwa data evaluasi termasuk dalam kategori Gizi Baik. 


\section{DAFTAR PUSTAKA}

[1] Turnip, F., 2008, Pengaruh “Positive Deviance" Pada Ibu Dari Keluarga Miskin Terhadap Status Gizi Anak Usia 12-24 Bulan di Kecamatan Sidakalang Kabupaten Dairi Tahun 2007, Tesis Universitas Sumatra Utara.

[2] Aries, M dan Martianto, D., 2006, Estimasi kerugian ekonomi akibat status gizi buruk dan biaya penanggulangannya pada balita di berbagai provinsi di Indonesia. Jurnal Gizi dan Pangan, Vol. 1, No. 2, pp 26-33

[3] BAPPENAS, 2010, Peta Jalan Percepatan Pencapaian Tujuan Pembangunan Milenium di Indonesia. Jakarta: Badan Perencanaan Pembangunan Nasional.

[4] Razak, AA., Gunawan, IMA., Budiningsari, R., 2009, Pola Asuh Ibu Sebagai Faktor Resiko Kejadian Kurang Energi Protein (KEP) Pada Anak Balita, Jurnal Gizi Klinik Indonesia, Vol. 6, No. 2, pp 95-103.

[5] Liu, B., 2007 . Web Data mining: Exploring Hyperlinks, Contents, dan Usage Data. Berlin: Springer.

[6] Wu X, Kumar V. 2009. The Top Ten Algorithms in Data Mining. New York: CRC Press.

[7] Banjarsari, MA., Budiman, HI., Farmadi, A., 2015, Penerapan K-Optimal Pada Algoritma Knn untuk Prediksi Kelulusan Tepat Waktu Mahasiswa Program Studi Ilmu Komputer Fmipa Unlam Berdasarkan IP Sampai Dengan Semester 4, Kumpulan jurnaL IImu Komputer (KLIK), Volume 02, No.02, pp 50-64.

[8] Mustakim dan Oktaviani, G., 2016, Algoritma K-Nearest Neighbor Classification Sebagai Sistem Prediksi Predikat Prestasi Mahasiswa, Jurnal Sains, Teknologi dan Industri, Vol. 13, No.2, pp.195 - 202.

[9] Kartika, JI., Santoso, E., Sutrisno., 2017, Penentuan Siswa Berprestasi Menggunakan Metode K-Nearest Neighbor dan Weighted Product (Studi Kasus : SMP Negeri 3 Mejayan), Jurnal Pengembangan Teknologi Informasi dan Ilmu Komputer, Vol. 1, No. 5, pp 352-360.

[10] Pressman, RS., 2001, Software Engineering: A Practitioner's Approach, Fifth Edition, McGraw-Hill Series in Computer Science.

[11] Han, J. dan Kamber, M., 2006, Data Mining: Concepts and Techniques. Second Edition, Morgan Kaufmann Publishers.

[12] Darmawan, A., 2012, Pembuatan Aplikasi Data Mining Untuk Memprediksi Masa Studi Mahasiswa Menggunakan Algoritma K-Nearest Neighborhood, Skripsi Universitas Komputer Indonesia

[13] Budiyanto, AK., 2009, Dasar-dasar Ilmu Gizi. Malang: UMM Press.

[14] Departemen Gizi dan Kesehatan Masyarakat FKM UI, 2010, Gizi dan Kesehatan Masyarakat, Jakarta: PT Raja Grafindo Persada. 
[15] Lutfiana, N., 2013, Faktor - faktor Yang Berhubungan Dengan Kejadian Gizi Buruk Pada Lingkungan Tahan Pangan dan Gizi, Skripsi UNNES. 